\title{
French university under fire for culling macaques
}

Primate scientists are criticizing a decision at the Louis Pasteur University in Strasbourg, France, to kill a research colony of Tonkean macaques (Macaca tonkeana) last month because the animals were infected with the herpes B virus.

The monkeys, at the Centre of Primatology, had never shown symptoms of disease, and scientists critical of the move say that the culling was scientifically and morally unjustified. But university officials say they were concerned that the virus could jump the species barrier to people working with the animals. In humans, the virus can cause fatal encephalomyelitis.

Some of the animals in the 14-strong colony had been used for up to 25 years by macaque ethologists. The species has an unusual way of resolving social conflicts, in which a third individual often tries to actively reconcile two fighting monkeys. There are few Tonkean macaques in captivity.

It has been known since the 1980s that the Strasbourg animals carried the virus, but it was not until more recently that the possibility of human contagion was realized. Safety protocols were implemented in 1998, when the colony was isolated in its own wooded enclosure. Scientists and keepers were required to wear protective clothing when entering the enclosure, although they rarely get close to the animals. Restrictions became tighter when a new veterinary surgeon joined the university in 2002 and research students were not allowed to enter. A new colony of 23 animals was bred from virus-free individuals.

The university has asked its primate ethologists, led by Bernard Thierry, not to speak to the press, but their colleagues elsewhere say that they were distressed to learn that the animals were killed without their knowledge on Sunday 31 August, when scientists and keepers were not present. "We were all shocked by this," says Elisabetta Visalberghi, a researcher at the Institute of Cognitive Sciences and Technologies in Rome, and president of the Italian Ethological Society.

The ethologists had been negotiating with the university for more than five years over the animals' fate, including talks with a sanctuary in San Antonio, Texas, over possibly accepting the macaques. But on 29 August, a university council confirmed a decision taken earlier in the summer to cull the animals.

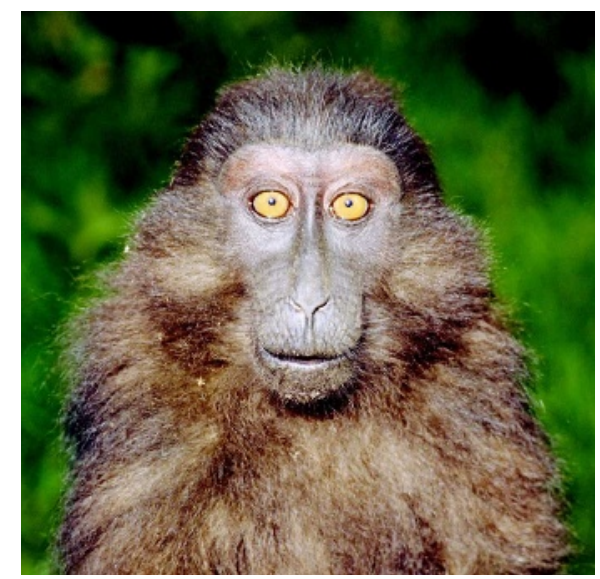

Herpes B is common in Tonkean macaques.

"It would be stupid to keep them for more time," says Nicolas Herrenschmidt, director of the centre. "The risk of transmission to humans is small, but it is there."

Juichi Yamagiwa at Kyoto University in Japan, who is president of the International Primatological Society, says macaque-to-human transmission of the virus is very rare, and the society has guidelines to ensure this does not happen. "I believe that no one would insist on killing infected monkeys if they have read these guidelines," he says.

Behaviouralist Frans de Waal works with macaques, many of which are infected, at Emory University's Yerkes National Primate Research Center in Atlanta, Georgia. He says he is "shocked that the deed has been done". He believes that "the risk, if managed properly, is not great enough to justify euthanizing these beautiful and interesting animals".

Hannah Buchanan-Smith, a primate behaviouralist at the University of Stirling, UK, says that the cull was "morally unacceptable". Research primates are not expendable once they have stopped being useful, she says. "We have a moral responsibility to look after them once we have used them, if, like these, they were able to lead happy lives."

But Alain Beretz, president of the Louis Pasteur University, says that the decision to kill the animals was made in a considered fashion over a five-year period. "We were not happy with the decision that we had to make," he says. "but we had to do it to protect our employees."

Alison Abbott 